\title{
Potential Impact of Climate Change on the Sediment Fluxes of a Watershed in West Africa: Cas of the Aghien Lagoon, Côte d'Ivoire
}

\author{
Wa Kouakou Charles N'dri ${ }^{1,2 *}$, Séverin Pistre ${ }^{2}$, Kan Jean Kouamé ${ }^{1}$, Jean Patrice Jourda ${ }^{1}$ \\ ${ }^{1}$ Laboratory of Sciences and Techniques of Water and Environment, Felix Houphouet-Boigny University of Cocody-Abidjan, \\ Abidjan, Côte d'Ivoire \\ ${ }^{2}$ Laboratory HSM, IRD, CNRS, University of Montpellier, Montpellier, France \\ Email: ${ }^{\star}$ drwakc17@gmail.com
}

How to cite this paper: N'dri, W.K.C., Pistre, S., Kouamé, K.J. and Jourda, J.P. (2022) Potential Impact of Climate Change on the Sediment Fluxes of a Watershed in West Africa: Cas of the Aghien Lagoon, Côte d'Ivoire. Atmospheric and Climate Sciences, 12, 18-30.

https://doi.org/10.4236/acs.2022.121002

Received: September 3, 2021

Accepted: November 21, 2021

Published: November 24, 2021

Copyright $\odot 2022$ by author(s) and Scientific Research Publishing Inc. This work is licensed under the Creative Commons Attribution International License (CC BY 4.0).

http://creativecommons.org/licenses/by/4.0/

\begin{abstract}
The semi-distributed SWAT (Soil and Water Assessment Tools) model was used in this study to model the sediment yield in the watershed of the Aghien lagoon with an area of $365 \mathrm{~km}^{2}$, located in the north of the district of Abidjan (South-East from Côte d'Ivoire). A sensitivity and uncertainty analysis, as well as calibration of the SWAT model, was conducted using the Sequential Uncertainty Adjustment Procedure (SUFI-2) which is one of the programs interfaced with SWAT in the SWAT-Cup package (SWAT-Calibration-Uncertainty Programs). Five parameters of the SWAT model were found to be more sensitive to sediment fluxes. These have been modified (calibration) sparingly in order to improve the reproduction of observed sediments data. Two measures were used to assess the uncertainty analysis of the model: P-factor and R-factor. The $\mathrm{R}^{2}$ and Nash-Sutcliffe (NS) coefficients of determination were used to assess the quality of the calibration. The P-factor obtained is 0.58 and the $\mathrm{R}$-factor is 2.28 . The NS and $\mathrm{R}^{2}$ coefficients in calibration over the period from June 2014 to January 2015 are 0.51 and 0.86 respectively. These values indicate correct consideration of uncertainties by the model and satisfactory calibration of the SWAT model for solid fluxes. Then, the model was used to simulate the sediment fluxes at the horizons 2040 (2035-2056), 2060 (2057-2078) and 2080 (2079-2100) in order to assess the impact of climate change on sediments in the watershed of the Aghien lagoon. The results indicate that sediment fluxes could increase in the future under the RCP 4.5 and RCP 8.5 scenarios. With RCP 4.5, sediment fluxes would increase on average by $14.42 \%$. They could increase by $17.95 \%$ on average under RCP 8.5 .
\end{abstract}

\section{Keywords}

Abidjan, Aghien, Calibration, Climate Change, Côte d'Ivoire, Sediment, SUFI-2, 


\section{Introduction}

The fresh water available on the earth's surface represents a low percentage, around $0.76 \%$ [1]. Despite this low availability, it has always been an essential element in human societies. Great civilization flourished when it was abundant, secured its access, or died out because of its absence. Today, human activities are subjecting resources to increasing pressure, until posing real problems of availability [2]. The uses of water for drinking water supply (DWS), industrial or agricultural needs, have led to unsustainable management of water resources. As proof, the availability of water per inhabitant has steadily decreased over the past decades, with significant inequality between the countries of the north and those of the south [2]. Côte d'Ivoire, like these countries, is facing this decline in the availability of its water resources under the pressures of climate change, human activities and population growth. For illustrative purposes, the Abidjan groundwater which serves as a drinking water supply for the Abidjan population is currently under strong pressure and can no longer meet the water needs of the populations of the Autonomous District of Abidjan. Indeed, a deficit of 58 million $\mathrm{m}^{3} /$ year of water must be mobilized to meet the pressing needs of this constantly growing population. The Ivorian government, therefore, considered exploiting the Aghien lagoon to make up for this deficit. The Aghien lagoon watershed, with an approximate area of $365 \mathrm{~km}^{2}$, is located in the South-East of the Côte d'Ivoire, precisely in the north of the district of Abidjan. The Mé, Djbi and Bété rivers are the main tributaries of the Aghien lagoon (Figure 1). The Aghien lagoon has great potential for a set of uses. Indeed, it constitutes a living space for the riparian populations, a buffer zone between the continent and the ocean and a water reserve for the addiction of drinking water and agriculture in the medium and long term. It was therefore retained by the Ivorian authorities as an alternative resource to make up for the water deficit estimated at 58 million $\mathrm{m}^{3} /$ year in the economic capital Abidjan [3]. In order to help Ivorian decision-makers to develop policies for better management of this lagoon in a context of climate change, a study on its quantitative availability was carried out by [4]. According to this study, the flow of the Aghien lagoon would decrease on average from 10\% (RCP 4.5) to $17 \%$ (RCP 8.5) in the future. In this same dynamic of helping decision-makers to effectively manage the Aghien lagoon, a study on its qualitative availability in this context of climate change is discussed in this paper. The objective of this paper is to assess the potential impact of climate change on sediment yield in the watershed of the Aghien lagoon using the SWAT (Soil and Water Assessment Tools) hydrological model coupled with six (6) climate models of the CORDEX-Africa project. 


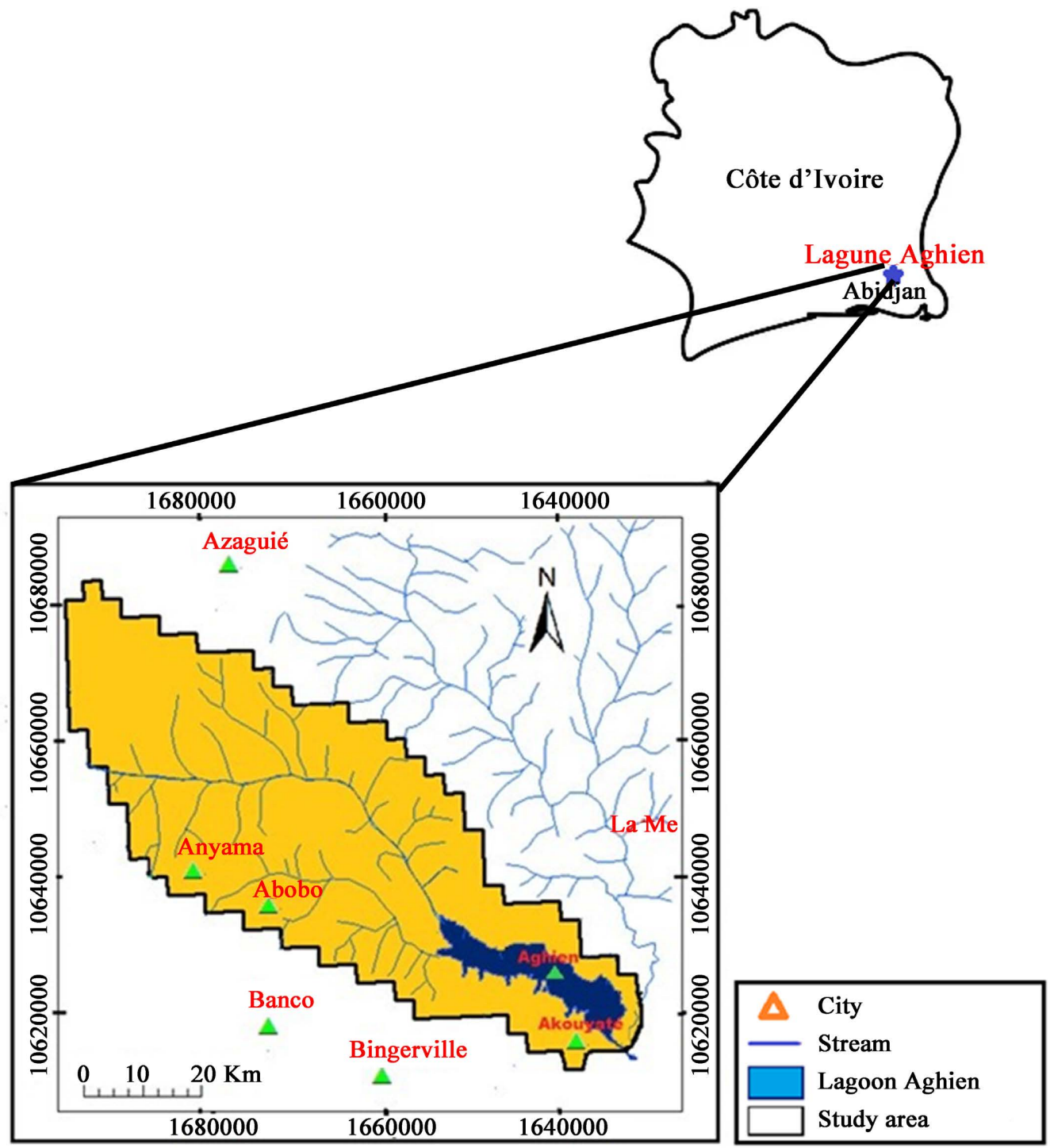

Figure 1. Location of the watershed of the Aghien lagoon.

\section{Data and Methods}

\subsection{Data}

The data used are described in the manuscript of [5]. These are: the digital Elevation model (DEM) data, the soil map and soil type data, the land use data of the Aghien lagoon watershed, meteorological data (precipitation, temperatures) from the period 1951 to 1998 and future climate data from 6 CORDEXAFRIQUE climate models for the RCP4.5 and RCP8.5 scenarios. These six (6) climate models are ISPL-CM5, HADGEM2, MIROC, MPI, CNRM and EC-EARTH. The delta method was required to correct for the bias of the six climate models [4]. All of these data were used to set up the hydrological SWAT model and to project the future flow [4]. Monthly sediment measurement data was also required. These measurements were taken (11 sampling points) at Anyama, Abobo debacardère, Akandjé, Aghien and Akouyaté (Figure 2). The surface 


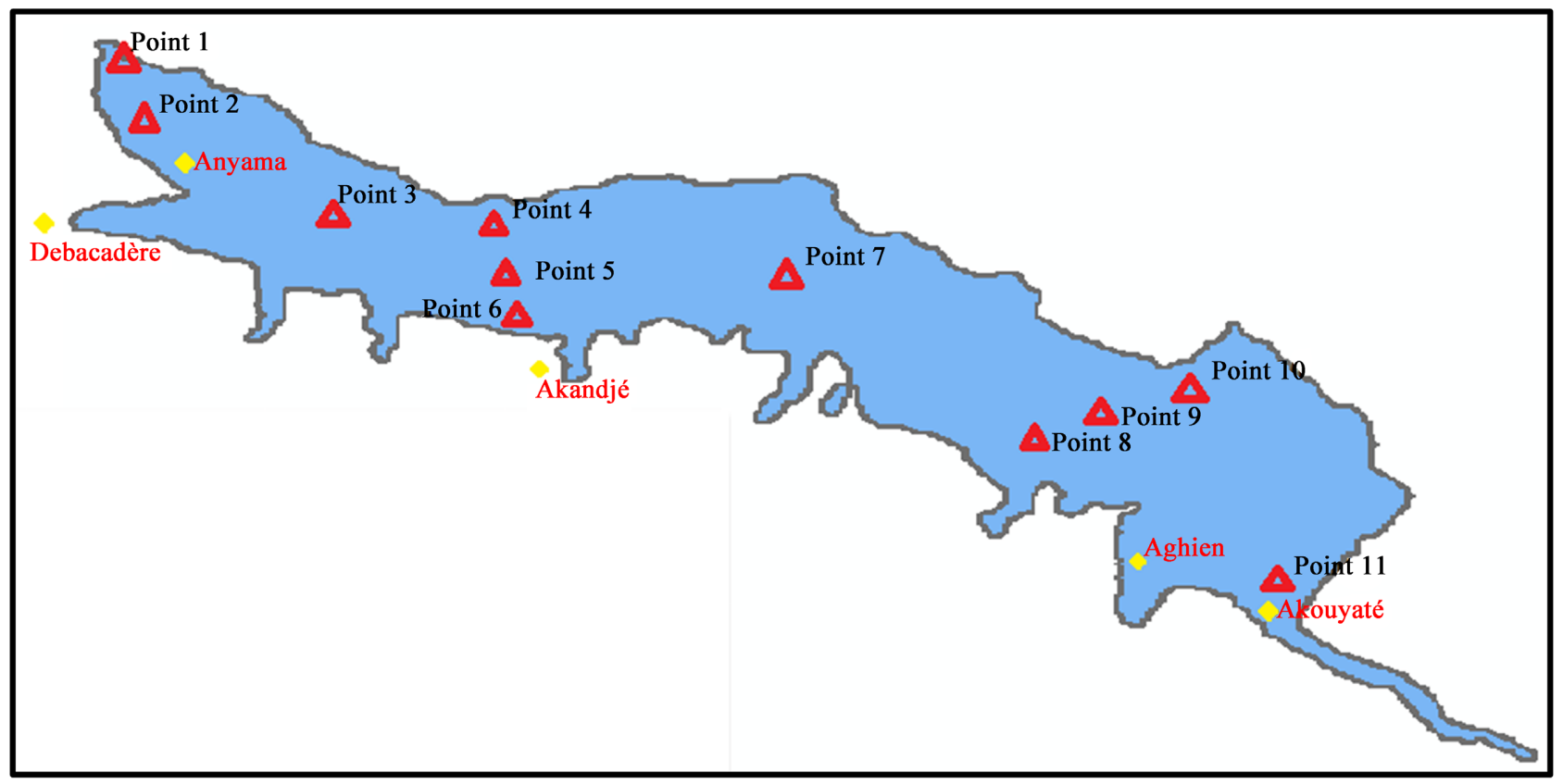

Figure 2. Sampling stations distribution (Institut Pasteur-June 2014-January 2015).

immersion sampling method was used to collect this data. Sampling was done once every three days on average. These sediment data were provided by the Institut Pasteur of Côte d'Ivoire. It's a public industrial and commercial establishment. His missions are research, training, diagnosis and epidemiological monotoring. These data covering the period from June 2014 to January 2015 and were therefore collected as part of the project to set up a permanent monitoring system for the Aghien lagoon.

\subsection{Methods}

SWAT-CUP (SWAT Calibration Uncertainty Procedures) is a platform that brings together different calibration and uncertainty analysis procedures for the SWAT model. SWAT-CUP brings together three procedures: Generalized Likelihood Uncertainty Estimation (GLUE [6], "Parameter Solutions" (ParaSol [7], Sequential Uncertainty Fitting (SUFI-2 [8]). This package is used because of its adaptation to SWAT projects, its ergonomic interface, its processing speed and its features which allow to create graphs or compare the different results between them. The SUFI-2 procedure proposes about ten objective-functions to optimize the calibration of the model, among these the Nash-Sutcliffe criteria and the coefficient of determination $\mathrm{R} 2$ which are the two objective-functions most used in this field [9]. These two statistical parameters are used to measure the performance of the model. Table 1 below presents the criteria for evaluating the performance of the SWAT model. Several iterations are required to update the parameter sets. Within the SUFI-2 program, all the parameters of the model are entered as well as their minimum and maximum potential values having a real physical meaning, in order not to obtain outliers. Thus, the parameters vary 
randomly between minimum and maximum values, simulation after simulation, decreasing the magnitude of the uncertainty, and focusing on the last "best" set of parameters.

For the SWAT model uncertainty analysis, two bands are compared: the 95PPU for model simulation and the band representing the measured data plus its error. Two indices called "P-factor" and "R-factor" are used for the analysis of the uncertainties of the SWAT model [12]. The P-factor is the fraction of the measured data (plus its error) in the 95PPU band interval and ranges from 0 to 1 , where 1 indicates $100 \%$ of the measured data within the model prediction uncertainty ( 1 indicates a perfect model simulation considering the uncertainty). The quantity (1 - P-factor) could therefore be called the model error. A P-factor value greater than 0.7 or 0.75 could be adequate for this factor according to [12]. This of course depends on the scale of the project and the adequacy of the input data and calibration. The $\mathrm{R}$ factor, on the other hand, is the ratio of the average width of the 95PPU band and the standard deviation of the measured variable. An R-factor value of less than 1.5, still depending on the scale of the project, would be desirable for this clue [8]. These two clues are used to judge the strength of calibration and validation. Bigger P-factor can be obtained at the expense of a bigger R-factor. Therefore, there is often a balance between the two factors. In the final iteration, when the acceptable values of R-factor and P-factor are reached, the parameter ranges are taken as calibrated parameters.

\subsection{Calibration and Validation of SWAT Model}

The calibration is carried out on the flow initially over the period 1960-1981 [5]. The Nash-Sutcliffe (NSE) and $\mathrm{R}^{2}$ determination coefficients in calibration (1960$1969)$ are 0.807 and 0.809 , respectively. In validation (1970-1981) $\mathrm{NSE}=0.59$ and $\mathrm{R}^{2}=0.64$. These values are greater than the guide value (0.5). According to [10] coefficients of NSE and $\mathrm{R}^{2}$ greater than 0.5 are acceptable and demonstrates the good performance of the SWAT model in reproducing the discharge. Thus, in view of values of the NSE and $\mathrm{R}^{2}$ coefficients obtained in calibration and validation, the SWAT model reproduced the discharge fairly faithfully [5]. Then, in a second step, the calibration was carried out on the sediments flows. In order to improve the reproduction of the observed point sediment data, the most sensitive model quality parameters (Table 2) for the simulation of sediment transport, eleven (11) according to the literature, have been modify. During this

Table 1. Criteria for evaluating the performance of the commonly used SWAT model [10] [11].

\begin{tabular}{ccc}
\hline Performance evaluation & Nash (NSE) & $\mathbf{R}^{2}$ \\
\hline Very good & $0.75<\mathrm{NS}<1.00$ & $0.75<\mathrm{R}^{2}<1.00$ \\
Good & $0.65<\mathrm{NS}<0.75$ & $0.65<\mathrm{R}^{2}<0.75$ \\
Satisfying & $0.50<\mathrm{NS}<0.65$ & $0.50<\mathrm{R}^{2}<0.65$ \\
Not satisfying & $\mathrm{NS}<0.50$ & $\mathrm{R}^{2}<0.50$ \\
\hline
\end{tabular}


Table 2. Most sensitive sediment transport modeling (SWAT) parameters (11).

\begin{tabular}{ccc}
\hline Parameters & Description of Parameters & Range of value \\
\hline SLSUBBSN & Average slope length & $10-150$ \\
HRU_SLP & Average slope steepness & $0-1$ \\
USLE_C & Soil occupation and conservation factor & $0.001-0.5$ \\
RSDIN & Initial residue cover & $0-10,000$ \\
BIOMIX & Biological mixing efficiency & $0-1$ \\
CH_COV & Channel cover factor & $0.04-0.6$ \\
SPEXP & Exponent for the transport of sediments in the channel & $1-1.5$ \\
USLE_P & Anti-erosion practices factor & $0.1-0.9$ \\
CH_EROD & Channel erodibility factor & $0-0.3$ \\
SPCON & Channel sediment routing parameter & $0.002-0.005$ \\
USLE_K & USLE soil erodibility factor & $-0.3-0.3$ \\
\hline
\end{tabular}

phase, calibration took place in two steps. First, a sensitivity analysis selects the most sensitive parameters among the eleven. Second, these parameters were adjusted to obtain a good matching between the sediment data observed and those simulated by the SWAT model.

\section{1) Sensitivity analysis}

The optimization process which reflects the sensitivity of the 11 parameters was carried out by the global sensitivity analysis method. Five hundred (500) simulations were performed to obtain the most sensitive parameters. The principle of this method is to assign values (within the range of limit values) to the most sensitive parameters described in the table above and to perform many simulations (500). After each simulation, the values of the t-Stat and P-Value coefficients obtained are compared with the previous ones. The $t$-Stat and P-Value coefficients (in SWAT-CUP) identify the most sensitive and least sensitive parameter. Thus a parameter having a larger absolute value of $\mathrm{t}$-Stat is more sensitive. The P-Value gives the importance of sensitivity. When P-Value is close to Zero then the sensitivity of the parameter is important.

2) Adjustment of the most sensitive parameters among the eleven selected

Once the sensitivity analysis was performed, the calibration of the SWAT model was performed against the sediment data. The SUFI-2 optimization algorithm [12] within SWAT-CUP 5.1.6 software was used. The principle consists in varying the value of the sensitive parameter by multiplying all of its values in each URH (R_Relative method) by the same coefficient until obtaining the best value of an objective function (the Nash-Sutcliffe coefficient (NS > 0.5) and the coefficient of determination $\mathrm{R}^{2}>0.5$, $\mathrm{R}$-factor and $\mathrm{P}$-factor). $\mathrm{P}$-factor values greater than 0.7 and $\mathrm{R}$-factor values less than 1.5 are recommended to obtain good modeling [13]. It should be noted that the sediment calibration was carried out throughout the 2014-2015 period for which the sediment data were available. 
The model was therefore not validated for sediment loadings because there was not a long series of sediment data in the basin studied to do it. The sensitivity analysis, calibration and validation procedure is shown schematized in Figure 3 below.

\section{3) Prospective simulation of sediment yield}

The outputs of the six corrected climate models are edited in "txt" format and then integrated into the SWAT model to simulate the sediment fluxes for the 2040 (2035-2056), 2060 (2057-2078) and 2080 (2079-2100) horizons. Once the future flows are simulated, they are compared with the flows simulated over the reference period 1960-1981. The comparison between future simulations and simulations over the reference period is made possible because the reproduction of the processes over time spent (1960-1981) was validated beforehand, during the calibration/validation phase of the SWAT model [5]. The goal is to see what would be the evolution of sediment flows in the watershed of the Aghien lagoon. The calibration parameters, the soil map and land use were kept constant.

\section{Results and Discussion}

\subsection{Sediment Calibration over the Period (2014-2015)}

\subsubsection{Sediment Sensitivity Analysis}

The sensitivity analysis makes it possible to identify the main parameters of the

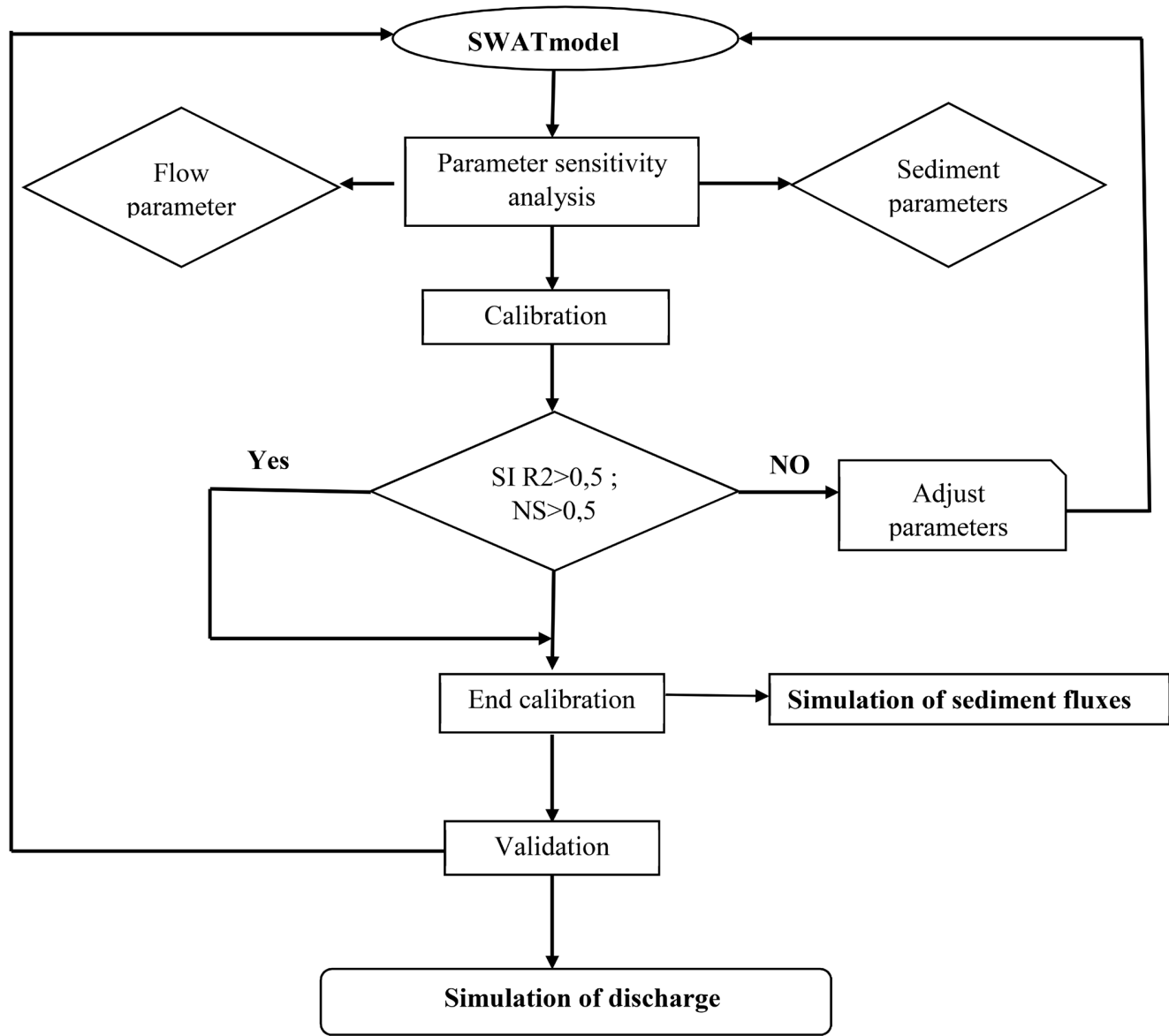

Figure 3. Diagram of the sensitivity analysis, calibration and validation procedure of the SWAT model. 
watershed and their precision required for calibration. A total of 11 model parameters were evaluated to determine their relative sensitivity to sediment in watershed of the Aghien lagoon. The results show that five of the parameters are the most sensitive with values of $\mathrm{P}$-values less than 0.6 and absolute values $\mathrm{t}$-stat between 13 and 0.45 . These parameters are: the soil occupation and conservation factor C (USLE_C), the anti-erosion practices factor P (USLE_P), SPEXP the exponent for the transport of sediments in the channel, the channel erodibility factor $\mathrm{CH}$ _EROD and $\mathrm{CH}$ _COV the vegetative cover factor of the channel. These are shown in Table 3, ranked from most sensitive to least sensitive.

\subsubsection{Adjustment of Sediment Sensitive Parameters}

He statistical summary of the evaluation of the model's performance in the BVLA shows the values of the coefficient of determination $\left(\mathrm{R}^{2}\right)$ and the P-factor of 0.86 and 0.58 respectively but also a relatively low value of NS of 0.51 . These values strongly suggest a good agreement between the observed sediment and simulated values. The R-factor (thickness of the uncertainty band) is 2.28 . This $\mathrm{R}$-factor value, much greater than 1.5 (guide value), highlights a certain level of uncertainty in the model with respect to the sediments. Nevertheless, the dynamics of sediment concentrations are fairly well represented as shown in Figure 4 even though the model underestimates the sediment concentrations in July

Table 3. Parameters sensitive to sediment transport simulation (SWAT model).

\begin{tabular}{cccc}
\hline Paramètres & t-Stat & P-Value & Sensitivity rank \\
\hline USLE_P & -13.321 & 0.00012 & 1 \\
USLE_C & 7.262 & 0.0015 & 2 \\
SPEXP & 2.076 & 0.0027 & 3 \\
CH_EROD & -0.741 & 0.651 & 4 \\
CH_COV & 0.411 & 0.57 & 5
\end{tabular}

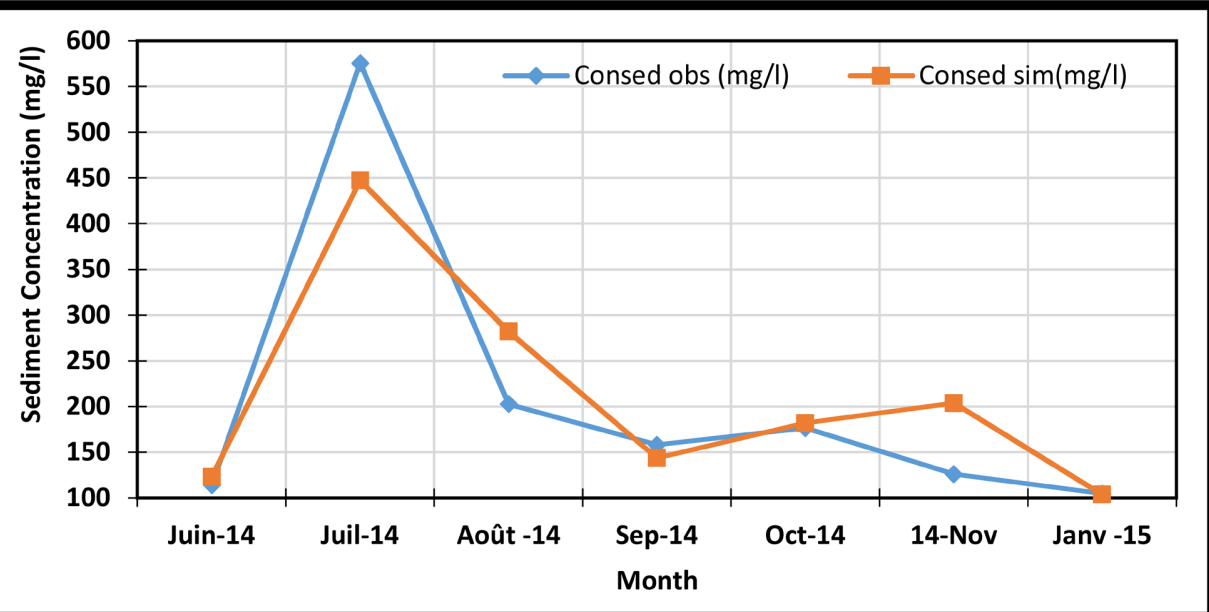

Figure 4. Hydrogram of monthly observed (blue) and simulated (red) sediment concentrations $(\mathrm{NS}=0.51 ; \mathrm{R}$-factor $=2.28$; P-factor $=0.58)$. 


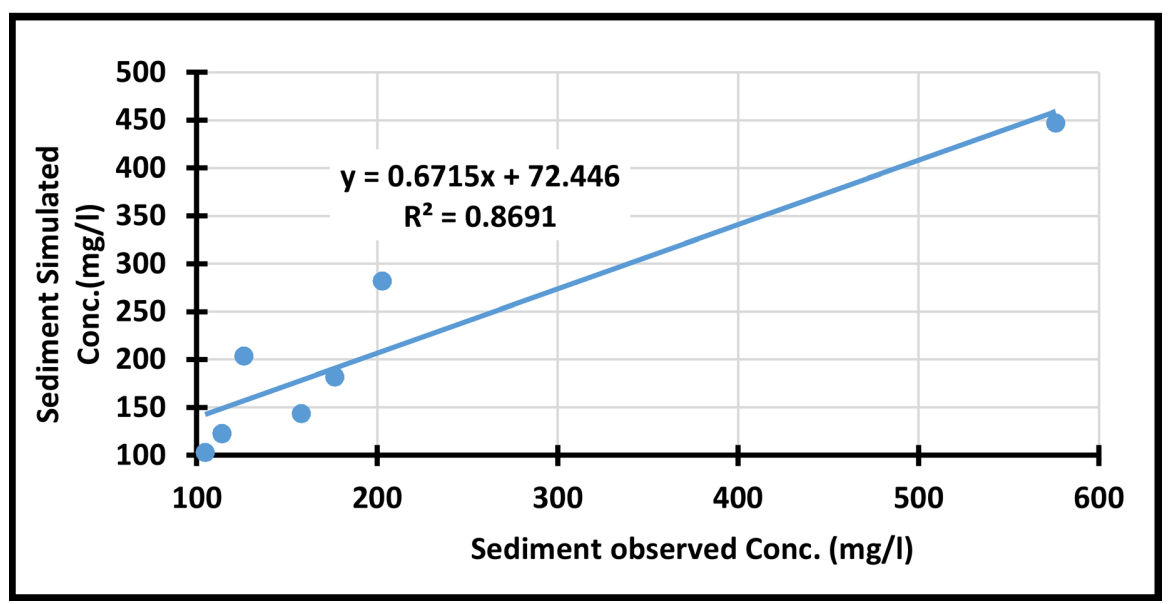

Figure 5. Correlation of monthly concentrations $\left(\mathrm{mg} / \mathrm{l}\right.$; equivalent to $\left.\mathrm{kg} / \mathrm{m}^{3}\right)$ observed and simulated for the calibration period June 2014-January $2015\left(\mathrm{R}^{2}=0.869\right)$.

2014 and overestimates them in November 2014. The dispersion of the concentrations of simulated and observed sediment are close to each other as shown in Figure 5, which shows that the simulation of sediment concentrations by the SWAT model is satisfactory.

\section{Evolution of Sediment Yield in the Watershed of the Aghien Lagoon}

The SWAT model was used to determine the impact of climate change on sediment Yield, by 2040, 2060 and 2080 horizons for the RCP 4.5 and RCP 8.5 climate scenarios. The annual sediments transported in the Aghien Lagoon watershed for the reference period (1960-1981) are $13.731 \mathrm{~kg} / \mathrm{ha} /$ year. Under the RCP 4.5 , scenario they are $15.558 \mathrm{~kg} / \mathrm{ha} /$ year, $15.605 \mathrm{~kg} / \mathrm{ha} /$ year, $15.974 \mathrm{~kg} / \mathrm{ha} /$ year respectively for the horizons 2040 (2035-2056), 2060 (2057-2078) and 2080 (2079-2100). Under the RCP 8.5 scenario, the annual flows of sediments transported in the catchment area of the Aghien lagoon, by 2040, 2060 and 2080 horizons are respectively $16.057 \mathrm{~kg} / \mathrm{ha} /$ year, $16.244 \mathrm{~kg} / \mathrm{ha} /$ year, $16.288 \mathrm{~kg} / \mathrm{ha} /$ year. Thus, the annual sediment flows would increase on average by $14.42 \%$ under RCP 4.5 and by $17.95 \%$ under RCP 8.5 . Seasonally, sediment flows could decrease during the short dry season (August, September): Under the RCP 4.5 scenario, they would decrease by $55.60 \%$ and under RCP 8.5 by $77.57 \%$. The flows should increase during the great rainy season (May-June-July) by $36.83 \%$ under RCP 4.5 and by $59.02 \%$ under RCP 8.5 . They could also be up during the great dry season (December to April) by $35.58 \%$ under RCP 4.5 and $40.08 \%$ under RCP 8.5. Finally, an increase in sediment flows of $37.43 \%$ and $51.05 \%$ is also expected during the short rainy season respectively under the RCP 4.5 and RCP 8.5 scenarios. The average rates of change of sediments flows modeled under RCP 4.5 for the base period for horizons 2040, 2060 and 2080 are respectively $11.12 \%, 14 \%, 29.12 \%$. Under the RCP 8.5 scenario, the average sediment variation rates forecast for the 2040, 2060 and 2080 horizons are $22.37 \%, 19.32 \%$ and 
$30.89 \%$ respectively. Table 4 shows the variations in annual and seasonal sediment fluxes at the horizons (2040 (2035-2056), 2060 (2057-2078) and 2080 (2079-2100)) under RCP 8.5 and RCP 4.5.

\section{Discussion}

The results of modeling the impacts of climate change on the quantitative availability of the Aghien lagoon obtained showed that the average of the 6 (six) CORDEX AFRIQUE climate models gives a decrease in precipitation, the flow of the lagoon and an increase in evapotranspiration in the future, which will accentuate the reduction in flows in the catchment area of the Aghien lagoon [4]. In fact, the flow of the Aghien lagoon would decrease by $8 \%, 10 \%$ and nearly $10 \%$ for the RCP 4.5 scenario respectively by 2040 (2035-2056), 2060 (20572078) and 2080 (2078-2100) and would decrease by 16\% by 2040 and by more than $18 \%$ by 2060 and 2080 for the RCP 8.5 scenario. Our study found that the annual sediment fluxes should increase by $14 \%$ under RCP 4.5 and nearly $18 \%$ under RCP 8.5. The trends in sediment yield and discharge do not occur in the same direction. Indeed, our results clearly demonstrate that the sediment yield

Table 4. Variations of sediment yield, annual and seasonal for the reference period (1960-1981) and future periods (2035-2056; 2057-2078; 2079-2100) under the RCP 4.5 and RCP 8.5 scenarios.

\begin{tabular}{|c|c|c|c|c|c|c|c|}
\hline \multirow[b]{2}{*}{ Scenarios } & \multirow{2}{*}{$\begin{array}{c}1960-1981 \\
\text { Baseline } \\
\text { period }\end{array}$} & \multicolumn{2}{|c|}{$2040(2035-2056)$} & \multicolumn{2}{|c|}{$2060(2057-2078)$} & \multicolumn{2}{|c|}{$2080(2079-2100)$} \\
\hline & & $\begin{array}{c}\text { sediment } \\
(\mathrm{kg} / \mathrm{ha})\end{array}$ & $\begin{array}{c}\text { variation } \\
(\%)\end{array}$ & $\begin{array}{c}\text { sediment } \\
(\mathrm{kg} / \mathrm{ha})\end{array}$ & $\begin{array}{c}\text { variation } \\
(\%)\end{array}$ & $\begin{array}{c}\text { sediment } \\
(\mathrm{kg} / \mathrm{ha})\end{array}$ & $\begin{array}{c}\text { variation } \\
(\%)\end{array}$ \\
\hline Annual (average) & 13,731 & 0 & 0 & 0 & 0 & 0 & 0 \\
\hline Great rainy season & 58,628 & 0 & 0 & 0 & 0 & 0 & 0 \\
\hline Great dry season & 59,097 & 0 & 0 & 0 & 0 & 0 & 0 \\
\hline Short rainy season & 26,687 & 0 & 0 & 0 & 0 & 0 & 0 \\
\hline Short dry season & 20,370 & 0 & 0 & 0 & 0 & 0 & 0 \\
\hline \multicolumn{8}{|l|}{ RCP 4.5} \\
\hline Annual (average) & & 15,558 & 13.30 & 15,605 & 12 & 15,974 & 16.33 \\
\hline Great rainy season & & 61,328 & 4.60 & 67455 & 15.05 & 68,700 & 17.18 \\
\hline Great dry season & & 70,148 & 18.69 & 63740 & 7.85 & 64,445 & 9.04 \\
\hline Short rainy season & & 29,402 & 10.17 & 30157 & 13 & 30,493 & 14.26 \\
\hline Short dry season & & 15,819 & -22.34 & 15907 & -21.90 & 18,055 & -11.36 \\
\hline \multicolumn{8}{|l|}{ RCP 8.5} \\
\hline Annual (average) & & 16,057 & 16.93 & 16244 & 18.29 & 16,288 & 18.61 \\
\hline Great rainy season & & 69,419 & 18.40 & 69419 & 18.40 & 71,661 & 22.22 \\
\hline Great dry season & & 67,357 & 13.97 & 65552 & 10.92 & 68,075 & 15.19 \\
\hline Short rainy season & & 30,443 & 14.07 & 30443 & 14.07 & 31,354 & 22.91 \\
\hline Short dry season & & 15,466 & -24.07 & 15466 & -24.07 & 14,374 & -29.43 \\
\hline
\end{tabular}


will increase even if the discharge decreases. Despite a decrease in precipitation, sediment loads keep going to increase, which could be due to an increase in temperature. Decreased precipitation and increased temperature can lead to water stress, which reduces plant growth and therefore worsens the rate of erosion. The study by [14] and [15] indicated that increased temperature can worsen the rate of soil erosion through its influence on vegetation and alteration, which can increase sediment flow in rivers. The study conducted by [15] in the Lower Pearl River Basin in China reported that a temperature increase of $3^{\circ} \mathrm{C}$ causes the rise of the sediment load by nearly $14 \%$. Under the two scenarios, in August and September, although the flow increases, the sediments fluxes decrease $(55.6 \%$ under RCP 4.5 and 77.5\% under RCP 8.5). The decrease in sediment fluxes during these months may be due to the significant influence of increased evapotranspiration and crop growth processes under warmer climate, as mentioned by [16]. Increased sediment loads can intensify many problems associated with the accelerated loss of lagoon storage through sedimentation and siltation of water distribution systems. This loss is associated with a reduction in the carrying capacity and increased water turbidity of the lagoon [17]. The increase in water turbidity can also have negative consequences on animal and vegetable biodiversity of the Aghien lagoon. Thus, in view of the evolution of sediment flows, a probable degradation of the water quality of the Aghien lagoon mainly caused by the increase in sediment could occur in the future.

\section{Conclusion}

The SWAT model was used to reproduce the sediment yield of the Aghien lagoon watershed located in the southeast of Côte d'Ivoire in the north of the district of Abidjan. There were limited sediment data available. The data available on sediment flows were limited to the period from June 2014 to January 2015. The model was therefore calibrated over this entire period and therefore was not tested over a validation period. Thus, the calibration of the SWAT model for sediments using SWAT-Cup version 5.1.6 was satisfactory with a Nash-Sutcliffe (NS) and determination $\left(\mathrm{R}^{2}\right)$ coefficient of 0.51 and 0.86 , respectively. Using a longer period of sediment data could improve calibration results and allow model validation for sediment. Nevertheless, given the good calibration results, simulations were carried out. The future trends (horizons 2040 (2035-2056), 2060 (2057-2078) and 2080 (2078-2100)) have shown that sediment yield could be up $14.42 \%$ under the RCP 4.5 scenario and $17.95 \%$ under the RCP 8.5 scenario. The quality of the lagoon's water could therefore be degraded in the future by an increase in sediment flows.

\section{Recommendation}

Solutions based on "biological engineering" could be implemented. For example, consideration should now be given to reducing sediment flow by using grass strips to limit runoff and prevent soil erosion. Shading in the immediate envi- 
ronment of the Aghien lagoon could also be ensured by afforestation of the banks in order to limit the increase in temperature which could lead to water stress, which will reduce plant growth and therefore worsen the rate of erosion of the ground. The decision-makers and managers of the Aghien lagoon basin should take into account the trends described by our results in the implementation of adaptation measures to climate change to ensure the sustainability of the said lagoon. Moreover, these results seem to be transposable to other watersheds with comparable geographical characteristics, particularly in the West African zone.

\section{Acknowledgments}

This reflection received financial support from the ERASMUS MUNDUS program through the KITE ((Knowledge Integration and Transparency in Education) mobility project. All our gratitude was to the authorities of this program. We would like to express our gratitude to Professor Séverin Pistre, professor of hydrogeology at the University of Montpellier, my academic supervisor of KITE program for his constructive suggestions and as well its collaborators who gave me the datasets that made this study possible. Finally, we would like to pay a final tribute to the professors Jourda Jean Patrice and Kouamé Kan of the Félix Houphouët Boigny University who agreed respectively to be Director and co-director of my thesis project.

\section{Data Availability Statement}

Some or all data, models, or codes used during the study were provided by a third party. Direct requests for these materials may be made to the provider as indicated in the Acknowledgments.

\section{Conflicts of Interest}

The authors declare no conflicts of interest regarding the publication of this paper.

\section{References}

[1] Musy, A. (2004) Hydrologie. Presses polytechniques et universitaires romandes, Lausanne, $314 \mathrm{p}$.

[2] Brulebois, E. (2016) Impacts du changement climatique sur la disponibilité de la ressource en eau en Bourgogne: Aspects quantitatifs et qualitatifs. Thèse de Doctorat en Sciences de la Terre, option Hydroclimatologie, Université de Bourgogne Franche-Comté, 322 p.

[3] Ehouman, S.K., Amidou, D., Djibril, D., Noufé, B., Kamagate, B., Koffi, J., Thierry, K., Seydou, D. and Droh, L.G. (2017) Bilan des apports liquides des rivières Bété et Djibi à la lagune aghien (Côte d'Ivoire). American Journal of Innovative Research and Applied Sciences, 6, 86-99.

[4] N'dri, W.K.C., Pistre, S., Jourda, J.P. and Kouamé, K.J. (2019) Estimation of the Impact of Climate Change on Water Resources Using a Deterministic Distributed Hydrological Model in Côte d'Ivoire: Case of Aghien Lagoon. Journal of Geoscience 
and Environment Protection, 7, 74-91. https://doi.org/10.4236/gep.2019.77007

[5] N'dri, W.K.C., Pistre, S., Jourda, J.P. and Kouamé, K.J. (2019) Application of SWAT to Estimate Water Balance in the Aghien Lagoon Basin, South-East of Côte d'Ivoire. International Journal of Science and Research (IJSR), 8, 10 p.

[6] Beven, K. and Binley, A. (1992) The Future of Distributed Models-Model Calibration and Uncertainty Prediction. Hydrological Processes, 6, 279-298. https://doi.org/10.1002/hyp.3360060305

[7] Van Griensven, A. and Meixner, T. (2006) Methods to Quantify and Identify the Sources of Uncertainty for River Basin Water Quality Models. Water Science \& Technology, 53, 51-59. https://doi.org/10.2166/wst.2006.007

[8] Arnold, Jef.G., Moriasi, D.N., Gassman, P.W., Abbaspour, K.C., White, M.J. Srinivasan, R., Santhi, C., Harmel, D., van Griensven, A., Van Liew, M.W., Kannan, N. and Jha, M.K. (2012) SWAT: Model Use, Calibration, and Validation. Biological Systems Engineering: Papers and Publications, 406.

https://digitalcommons.unl.edu/biosysengfacpub/406/

[9] Arnold, J.G., Kiniry, J.R., Srinivasan, R., Williams, J.R., Haney, E.B. and Neitsch, S.L. (2012) Soil \& Water Assessment Tool. Input/Output Documentation. Texas Water Resources Institute, College Station, TR-439, 654 p.

[10] Santhi, C., Arnold, J.G., Williams, J.R., Dugas, W.A., Srinivasan, R. and Hauck, L.M. (2001) Validation of the SWAT Model on a Large River Basin with Point and Nonpoint Sources. JAWRA, 37, 1169-1188. https://doi.org/10.1111/j.1752-1688.2001.tb03630.x

[11] Van Liew, M.W. and Garbrecht, J. (2003) Hydrologic Simulation of the Little Washita River Experimental Watershed Using SWAT. JAWRA, 39, 413-426. https://doi.org/10.1111/j.1752-1688.2003.tb04395.x

[12] Abbaspour, K.C., Johnson, C.A. and van Genuchten, M.T. (2004) Estimating Uncertain Flow and Transport Parameters Using a Sequential Uncertainty Fitting Procedure. Vadose Zone Journal, 3, 1340. https://doi.org/10.2136/vzj2004.1340

[13] Abbaspour, K.C., Rouholahnejad, E., Vaghefi, S., Srinivasan, R. and Klöve, B. (2015) A Continental-Scale Hydrology and Water Quality Model for Europe: Calibration and Uncertainty of a High-Resolution Large-Scale SWAT Model. Journal of Hydrology, 524, 733-752. https://doi.org/10.1016/j.jhydrol.2015.03.027

[14] Zhu, Y.-M., Lu, X.X. and Zhou, Y. (2008) Sediment Flux Sensitivity to Climate Change: A Case Study in the Longchuanjiang Catchment of the Upper Yangtze River, China. Global and Planetary Change, 60, 429-442. https://doi.org/10.1016/j.gloplacha.2007.05.001

[15] Li, Y., Chen, B.M., Wang, Z.G. and Peng, S.L. (2011) Effects of Temperature Change on Water Discharge, and Sediment and Nutrient Loading in the Lower Pearl River Basin Based on SWAT Modeling. Hydrological Sciences Journal, 56, 68-83. https://doi.org/10.1080/02626667.2010.538396

[16] Bogaart, P.W., Van Balen, R.T., Kasse, C. and Vandenberghe, J. (2003) Process-Based Modeling of Fluvial System Response to Rapid Climate Change I: Model Formulation and Generic Applications. Quaternary Science Reviews, 22, 2077-2095. https://doi.org/10.1016/S0277-3791(03)00143-4

[17] Walling, D.E. (2008) The Changing Sediment Load of the Mekong River. Ambio, 37, 150-157. https://doi.org/10.1579/0044-7447(2008)37[150:TCSLOT]2.0.CO;2 